\title{
Funding Constraints for Latino Business Start-Ups
}

\author{
Marcelo E. Siles \\ Michigan State University \\ Rubén O. Martinez \\ Michigan State University
}

This study focusses on the high growth of Latino-owned businesses (LOBs) in the United States during the last two decades and the constraints these businesses face during their start-up and development stages. During this period, the number of LOBs increased faster than businesses owned by other racial and ethnic groups. The study also addresses the following aspects of Latino business ownership: 1) the main reasons U.S. Latinos decide to become business owners; 2) their reluctance to seek loans from formal financial markets; 3) internal and external factors that limit Latino business owner participation in financial markets, 4) and the internal and external factors that banks and other financial institutions face when working with Latino businesspeople. We found important gaps in access to credit between LOBs and two comparison groups: i) Equally-Latino \& non-Latino firms and ii) White-owned businesses.

Keywords: Latino-owned businesses, barriers to start a business, access to credit, financial markets

\section{INTRODUCTION}

In this study we describe and analyze several constraints that Latinos in the United States face when they decide to start up a new business. We use the terms Latinos and Hispanics interchangeably. The label Latinos is used for the overall subpopulation and Latinas is used to denote women within the subpopulation. In general, Latinos face a lengthy process rife with barriers and challenges when deciding to start a business. Barrier factors include low educational attainment, lack of previous business management experience, limited business relationships, and low levels of English language fluency. Their most challenging constraint is the lack of financial capital or sufficient funds that allow them to cover the start-up costs and the operating expenditures needed for sustainable business operations.

In this study we address the following four questions:

1. What are the main reasons Latinos in the U.S. become business owners?

2. Why are Latino business owners reluctant to participate in formal financial markets to obtain funds to start and support their operations?

3. What are the internal and external factors that prevent Latino business owners from participating in financial markets?

4. What are the internal and external factors that banks and other financial institutions face in serving Latino businesspersons? 
The Latino population in the United States has increased rapidly since the 1980s, outpacing the growth rates for Whites and African Americans. Latinos in the United States are estimated to number 60.1 million, which represents $19.5 \%$ of the total U.S. population. This has occurred as deaths exceeded births over the last decade among non-Hispanic White Americans. Population forecasts show that by 2050 the Latino population will represent approximately $30 \%$ of the country's population.

This population is not a homogenous one; it is comprised largely of Mexican Americans, Puerto Ricans, Cubans, Mexicans, Spaniards, Central Americans, and South Americans. In addition, there is a clear difference between native- and foreign-born Latinos. The percentage of foreign-born Latinos was increasing from 1980 through 2000 , when they reached a plateau of $40.1 \%$ of the total Latino population. The latest figure for 2015 was equal to $34.4 \%$ (Flores, 2017).

Related to increases in the Latino population, the number of Latino-owned businesses (LOBs) also has been increasing. Recent figures published by the U.S. Hispanic Chamber of Commerce (USHCC) indicate that there are over 4.37 million Latino-owned businesses, compared to 1.57 million in 2002 (USHCC, 2017). Over the last two decades there occurred an increase of 2.8 million new firms, reflecting a growth rate of $178.3 \%$. Over the past decade Latino businesses increased by $34 \%$ compared to $1 \%$ for all business owners (Orozco, Tarque, Oyer \& Porras, 2020). In the last ten years, the sales and receipts of LOBs increased by $35.1 \%$ (U.S. Bureau of the Census, Economic Census, 2017).

Latinos' educational attainment, unemployment rates, self-employment rates, and previous business experience of each of the subgroups are other factors for the increase in the number of Latino-owned startup businesses. Foreign-born Latino business owners tend to have higher levels of education, previous business experience, are bilingual, and have the highest business ownership and start-up rates among all Latino groups. Another important characteristic of LOBs is that they tend to be located, as one would expect, in areas with high concentrations of Latino populations; that is, regionally. According to projections by Geoscape for 2017, the South Atlantic region has the highest number of Latino firms, 6.68 million, followed by the Pacific with 5.33 million, and the East North Central with 4.1 million firms (Geoscape, 2017). Cubans and South Americans are concentrated in the South Atlantic region, while Mexicans in the Pacific and East North Central regions.

Notwithstanding the robust growth in the number of LOBs and in the scope of their operations, Latinoowned firms have higher failure rates and lower sales and receipts relative to White- and Asian-owned firms (Martinez, Avila, Santiago \& Tello Buntin, 2011; Quezada, 2018). As such, it is important to understand the factors that support and hinder them.

There are two well-known reasons that lead to Latinos establishing new businesses. The first is the "push factor," which holds that Latinos create new businesses mainly due to the discrimination they face in the labor market, in many cases because of their language limitations and low education levels. Immigrants especially lack supportive networks that facilitate access to information regarding job openings and referrals to potential employers. Mexican immigrant entrepreneurs confront a mix of challenges that disadvantage them when seeking employment compared to other immigrant business owners (Starr, 2012).

The second is the "pull factor." For example, many immigrants from Cuba and South America come to the U.S. searching for business opportunities, tend to have higher levels of education, funds for the initial investment, previous business experience, and extended networks of business and social relationships. Business opportunities are a key factor that draws them to the U.S. At the national level, these Latino immigrants create a higher percentage of new businesses than their local counterparts.

\section{LITERATURE REVIEW}

The number of self-employed workers has been steadily increasing in the last few years. About 1 in 9 workers was self-employed in 2009. In general, self-employment has been more common among men, Whites, Asians, and older workers, and in key industrial sectors such as agriculture, construction, and services industries. Self-employment is an important source of jobs in this country. In 2009, up to 15.3 million individuals were self-employed, including business owners with incorporated and unincorporated businesses. The self-employment rate, which consists of the proportion that self- employed persons 
comprise of total employment, was $10.9 \%$. Of those who were self-employed, approximately 9.8 million were unincorporated and 5.5 million were incorporated (Hipple, 2010).

The number of minority entrepreneurs its lower when compared with their share of the population, but entrepreneurship is on the rise among minority groups and the growth in the number of minority-owned businesses is much higher than their population growth from 2007 to 2012 (Office of Advocacy of the U.S. Small Business Administration, September 2016). For example, while the Black/African American population increased during this period by only $6 \%$, their business ownership increased by $34 \%$. At the same time, Hispanic-owned businesses increased by $46 \%$ while the Hispanic population increased by $17 \%$.

BusinessWire (2017), on the basis of a Geoscape study on the growth of Latino businesses, reports that the number of Hispanic-owned businesses increased by $31.6 \%$ since 2012 , more than double the growth rate of all businesses in the U.S. (13.8\%). It also reports that according to the Kauffman Index of Entrepreneurial Activity (2016), the Latino share of new entrepreneurs represented $24 \%$ of all firms, compared to $10 \%$ a decade ago - a 140\% increase. Latinos are 1.5 times more likely than members of the general population to start a business. An interesting feature of these businesses is that foreign-born Latinos have a larger percentage of firms than those owned by native-born Latinos (Bernstein, 2016; Geoscape, 2017). In addition, businesses owned by Latinas also experienced a rapid growth, reaching close to $50 \%$ of the total number of Latino-owned firms. Studies also show that the rates of increase in receipts by LBOs have increased steadily in the last decade, outpacing the figures for the total population (LEI 2017).

Light and Bonacich (1988) report that "the revival of small business and the resurgence of immigrant entrepreneurship were contemporaneous and compatible ... Because growth of self-employment exceeded the immigration needed to explain it, one concludes that resurging self-employment created a favorable context for immigrant entrepreneurship, and, in this sense, caused it". The authors discuss the difference between the concepts of immigrant and ethnic entrepreneurships: they define immigrant entrepreneurship as self-employment within the immigrant group at a rate much in excess of the general rate, and ethnic entrepreneurship as ethnic minority specialization in self-employment without, however, imposing the requirements of foreign-born origin.

Martinez and Avila (2019) studied the motivations for entrepreneurship among Latinos and White Americans. They found that the top two motivations Latino business owners ranked for starting a business are financial (gaining financial security for my family) and self-realization (utilizing my skills and abilities). White business owners, by contrast, rated two self-realization motivation items ("gaining the satisfaction of owning a business" and "utilizing my skills and abilities"), as their top two motivations for starting a business. This study also found that Latino business owners face structural inequalities that often 'push' them into business ownership as an approach of circumventing racism and low wages or other barriers to earning a living in the mainstream labor market.

A comparison by Dávila and Mora (2013) of self-employment rates between Latinos and non-Latinos during the first decade of the century shows that when the national economy was experiencing a downward trend, the entrepreneurial inclinations of non-Hispanics followed this trend even during 2010 when the economy was starting to recover. On the other hand, during the first half of the decade the self-employment rates of Latinos followed the downward trend. However, their entrepreneurial inclinations during the second half of the decade shifted in the opposite direction from that of non-Latinos. That is, it began to increase.

The authors focus on the factors that influence the self-employment decision and self-employment survival when addressing the question "what might explain the resilience of Hispanic self-employment rates in the face of a slowing economy in the second part of the decade?" (p. 4). They examine business ownership from personal and group perspectives and find that personal decisions are based on the relative returns from entrepreneurial employment, human capital, and credit access from their families and external institutions. From the group perspective, their entrepreneurship decisions are based on the importance of labor market discrimination and social capital.

A report from the Latino Entrepreneurship Initiative at the Stanford Graduate School of Business (2017) shows that "Between 2007 and 2012, the growth rate of both non-employer and employer Latino firms nearly outpaced the growth rate of White, Asian, and Black-owned firms combined. Without the increased numbers of Latino firms created during that period, the total number of firms in the United States would 
have decreased" (p. 6). The report concluded that Latino businesses are growing at a rate faster than that of the U.S. Latino adult population, and Latino entrepreneurs exhibit strong enterprising qualities through their engaged networking, above-average levels of higher education, and strong family histories of entrepreneurship. In addition, the report states that "Entrepreneurship allows a vulnerable segment of this population, undocumented immigrants, to overcome the structural barriers to employment in the United States as federal and state laws do not require proof of immigration status to start a business" (p. 10).

Studies of differences in entrepreneurial areas selected by men and women show that they tend to start different types of businesses and that profitability differs by type of enterprise. Female-owned businesses are mainly in services, restaurants, and retail sales sectors, while male-owned businesses are concentrated in the financial, construction, and in the automotive-related industries (Olivas and Frankwick, 2016).

Latino business owners face many challenges when they decide to start a business and during the developing process of their operations. Coronado and Martinez (2018) report, based on a qualitative study of $32 \mathrm{LOBs}$ in three Michigan cities, some of these challenges. The authors cite among the most important challenges the lack of access to loans provided by banks and other financial institutions, language constraints, envy, racial and sexist incidents and how they respond to them, and intragroup competition by fellow Latino entrepreneurs. They also argue that minority business owners, including Latinos, face significantly higher loan-application rejection rates, tend to pay higher interest rates on their loans than their White counterparts, and have depended on unconventional funding sources when starting a business. Support from family and friends, along with social capital, have often been the sources of funding for Latino start-up businesses.

According to these authors, another concern for Latino business owners is the perceived lack of trust (the basis for developing social capital) within and support from the Latino community itself. Participants in the study spoke of a degree of intra-ethnic competition occurring among Latino business owners. A minority of them claimed that members of their own group are not always welcoming of Latino businesses and believed that envidia (envy) is directed toward their businesses in different ways.

Latinos in general and LOBs in particular are becoming an important asset for the U.S. economy. The LDC US Latino GDP Report by Hamilton, Feinup, Hayes-Bautista and Hsu (2019) noted that the Latino gross domestic product is $\$ 2.3$ trillion. They are a critical component of the labor force. A report from New American Economy (2017) indicates that in 2015, they made up one out of every three agriculture workers in the United States. They also accounted for more than one in four workers in construction and more than one out of every seven of the country's entrepreneurs. Their high level of workforce participation has helped make them such a force in our economy. The report also shows that "In the last decade, entrepreneurship among Latinos has been growing rapidly ... between 1990 and 2012, the number of Hispanic entrepreneurs tripled, going from 577,000 to more than 2 million. Among foreign-born Latinos, the growth in the population of entrepreneurs was particularly notable. The number of self-employed Hispanic immigrants more than quadrupled between 1990 and 2012 - reaching 1.4 million by 2012" (p.13).

A study by Carpenter and Loveridge (2018) on ethnicity and business ownership found that Hispanic American business owners are more likely to be located in rural areas than other minorities and in counties with a relatively high percentage of individuals having less than a high school degree. They also note that Mexican American business owners borrow more from family, close friends, suppliers, and credit cards and have a lower proportion of bank loan debt than Korean American business owners.

Another important feature is that Latino entrepreneurs are less likely to access and use new technological applications in their business operations. Their commitments to strong social ties may impact the opportunity cost of using social technology rather than technology for business purposes. Latino business entrepreneurs tend to use more linguistic communication technology than financial management technology. The cultural influence of collectivism, strong socialization, and community orientation highlight the importance of strong ties in their business affairs, which are reinforced through social media connections (Williams, Gavino, and Jacobson, 2017).

Latinos own fewer financial products than the general population, place emphasis on potential retirement needs, receive less contact from advisors but are open to advice, rely on friends and family for information, and their key barrier to participation in financial markets is a lack of trust (Prudential, 2014). 
A review of the literature on banking operations and their relationships with Latino households and business owners reveal interesting issues. A study on unbanked and underbanked households conducted by the Federal Deposit Insurance Corporation (FDIC, 2017) found that $6.5 \%$ of U.S. households did not have anyone with a checking or savings account; these households are considered "unbanked." Approximately $18.7 \%$ of U.S. households had a checking, savings, or another type of account at a federal or state chartered financial institution, and also obtained financial products or services outside of the banking system with money transfers becoming the most common.

A household was categorized as underbanked if it had a checking or savings account and used an alternative financial services (AFS) provider in the previous 12 months for money orders, check cashing, international remittances, payday loans, refund anticipation loans, rent-to-own services, pawn shop loans, or auto title loans.

African American and Hispanic households had the highest unbanked and underbanked rates among all racial and ethnic groups (FDIC, 2017). Some of the top reasons that unbanked households offer for lacking a bank account include: 1) not having enough money to keep an account, 2) not trusting banks, 3) privacy concerns, 4) high account fees, 5) unpredictable account fees, 6) previous problems with credit or bank account, 7) needed products or services not offered, 9) inconvenient bank hours, and 10) inconvenient bank locations.

Household savings are the primary source for funding Latino start-ups and business development. The savings rates for Hispanic households increased from $42.5 \%$ in 2015 to $48.2 \%$ in 2017 , reflecting a net increase of $5.7 \%$ in two years. This increase was due mainly to savings rate increases among younger households, which were higher than those among older households. There is an important difference on how savings are made among unbanked, underbanked, and fully banked households. The first group generally saved using informal methods, keeping their savings in their homes or with family and friends, while the underbanked and fully banked households usually saved by using savings accounts.

The FDIC reports huge differences among racial and ethnic groups in accessing mainstream credit, as well as among unbanked, underbanked, and fully banked households. Among ethno-racial groups, 36.0\% of Black, $31.5 \%$ of Hispanic, and $14.4 \%$ of White households did not have access to mainstream credit, while $80.2 \%$ of unbanked, $21.9 \%$ of underbanked, and $14.1 \%$ of fully banked households did not have access to mainstream credit in 2017.

Banks are continually trying to develop sustainable relationships with unbanked, underbanked, and low- and moderate-income (LMI) consumers by learning about their financial demands and how banks could provide the desired types of products and services. Banks were also interested in determining how to develop and implement appropriate strategies in order to better serve these consumers, and the ways they can improve their capacity to develop sustainable relationships with them (Rengert and Rhine, 2016).

According to Rengert and Rhine (2016), banks are pursuing five strategies to achieve those relationships:

1. Recognize that Trust is the foundation for Strong Relationships with Unbanked and Underbanked Consumers. ... [B]uild or increase unbanked and LMI consumers' trust in banks is a necessary first step to increasing their participation in the mainstream financial system.

2. Adopt a Multi-Pronged Approach to Serving LMI Consumers. ... [H]iring branch staff who have cultural familiarity with area residents, engaging in strategic partnerships, and offering an appropriate variety of products and services to meet the needs of the local community.

3. Nurture Longer-Term Relationships with Community Partners. ... [T] significant commitments from banks and their partners. Better communication about shared goals and metrics is likely to lead to greater successes for all participants.

4. Use Technology to Increase Efficiencies for the Bank, Its Partners, and Its Customers. ... [T] echnology is a crucial battleground on which competition between bank and nonbank financial services providers takes place, and

5. Develop an Understanding of Unbanked and Underbanked Consumers in the Bank's Market area. ... Products and strategies that will attract the interest of a consumer who is unbanked because she thinks she does not have enough money for a bank account will likely be different 
from those that will attract the interest of a recent immigrant unfamiliar with the U.S. banking system (p. 2).

Latino immigrants are a profitable new market for financial institutions. Kelderhouse (2002) argues that Latinos are loyal to businesses that treat them well, are conservative with their money, and avoid risk. According to the author, banks are currently employing tactical practices to reach the Latino immigrant population. They employ bilingual Spanish-speaking staff, hire staff members from the branch's immediate community, and provide sensitivity/diversity training for bank personnel. They also become involved in community organizations, offer financial education classes to community group clients, sponsor booths at ethnic, cultural, and religious festivals, partner with faith-based organizations, sponsor school events, design their branches in a friendly and appealing manner, offer convenient hours, offer products that customers want, provide bilingual electronic services, and offer low-cost wire transfers and free calling cards.

In summary, the Latino population in the United States has increased substantially in the last few decades and is a major force of the nation's economy. The country has experienced increases in the number of Latino-owned businesses even during the recession of 2007-2009. Previous studies show that the majority of Latino business owners, especially Mexicans and Central Americans, are "pushed" into selfemployment or business ownership due to the challenges they face in the labor markets. These new business-owners face many challenges to start their businesses, especially given the limited fluency in English and their low educational levels. Among the most important are the lack of access to formal financial markets and relying on their own savings and monies (loans) from their relatives and close friends.

Other Latinos, such as Cubans and South Americans, are "pulled" by market opportunities in this country to establish their own businesses. They come to the U.S. looking for business opportunities based on their domestic and international business connections, high educational levels, and their fluency in English. Some of them already have established relationships with the banking industry.

Latino-owned businesses are gaining an important role within the U.S. economy: not only are their numbers growing, but their businesses show substantial increases in sales and receipts, business revenues, and profits. The banking industry found that Latino-owned businesses create huge market opportunities (\$1.4 trillion). In response, some banks are making important changes in their facilities and offering specially designed products to attract the large number of unbanked and underbanked Latino households, and to do business with the owners of more than 4.4 million Latino-owned businesses.

\section{METHODOLOGY}

The statistical analyses presented in this paper are based on secondary data from the U.S. Bureau of the Census. Three different datasets (U.S. Census, Survey of Entrepreneurs for 2014, 2015, and 2016) were utilized to: 1) describe the financial sources Latinos that start firms use to fund their initial operations, 2) the sources and amounts required for their operations, and 3) the reasons why Latino business owners are reluctant to participate in formal financial markets. These datasets include data by racial and ethnic group but only for firms with employees. For comparison purposes, we extracted data related to three different groups of business: 1) Latino-owned, 2) Equally owned by Latinos and non-Latinos, and 3) White-owned businesses. We estimated three-year averages for the selected racial and ethnic groups included in the study, and since this study focuses on start-up firms, we present data only for firms with less than 2 years in business.

\section{PARTICIPATION OF LATINO-OWNED FIRMS IN THE FINANCIAL MARKETS}

In recent years, Latino households and LOBs have experienced increasing access to formal financial markets. There are increases in the utilization of financial services in their daily activities and business operations. As shown in Table 1, the percentage growth of all financial services utilized by Latinos is substantial. There is a significant difference in the growth by Latinos and non-Latinos in the use of these financial services. Latinos made gains in the use of standard financial products, especially in opening 
Checking and Savings accounts (61\%), 529 accounts (59\%) giving high importance to the education of their children, and $401 \mathrm{~K}$ accounts (57\%) to support their retirement income.

The most important constraint LOBs with small operations face is the lack of access to credit in formal financial markets. Researchers agree that there are internal and external factors regarding the relative lack of access by LOBs to credit in these markets, which have made LOBs reluctant to seek bank loans and search for alternative funding sources.

We found the following internal reasons Latinos do not use formal lenders: 1) a culturally informed reluctanance to assume debt and take financial risks, 2) language barriers, and 3) low educational attainment levels. A high percentage of LOBs lack previous business experience, have low personal and/or business credit scores, and do not have extensive business networks, well-developed business plans with the required financial statements, or the necessary collateral to support the loans.

The most important external reasons LOBs do not have access to credit markets are: 1) discrimination they face by the banking industry, indicated by the number of loan applications rejected compared with other racial groups, 2) high interests charged on their loans, 3) lack of bank agencies in Latino predominant neighborhoods or close to where Latino businesses are located, 4) conflict with the hours of banks' operations and the time when LOB managers can visit the bank, and 5) the lack of culturally competent and Spanish-speaking staff at banks.

\section{TABLE 1}

\section{PERCENTAGE GROWTH OF FINANCIAL SERVICES USERS BY RACE/ETHNICITY, 2012-2017}

\begin{tabular}{|l|c|c|}
\hline \multicolumn{1}{|c|}{ Financial Service } & Latino & Non-Latino \\
\hline Debit/ATM Card & $37 \%$ & $17 \%$ \\
\hline Checking/Savings & $61 \%$ & $17 \%$ \\
\hline Credit Card & $36 \%$ & $13 \%$ \\
\hline Mortgage & $30 \%$ & $9 \%$ \\
\hline Auto Loan & $31 \%$ & $1 \%$ \\
\hline $401 \mathrm{~K}$ & $57 \%$ & $31 \%$ \\
\hline Personal Loan & $29 \%$ & $27 \%$ \\
\hline 529 College Savings Accounts & $59 \%$ & $-0.2 \%$ \\
\hline
\end{tabular}

Source: The TransPerfect Finance Team, Global Business (2018).

https://www.census.gov/library/publications/2012/econ/2012-sbo.html

\section{Funding Sources for Latino Start-Up Businesses}

Most Latino business owners rely on their own funds to start up their operations. They count on their own and family savings, loans and investments from family and friends, loans from suppliers, and personal/business credit cards. Among all firms, we found that $77 \%$ of Latino firms rely mainly on trade credit from suppliers, $76 \%$ count on credit cards, and over $67 \%$ obtained some type of loan from family, friends, and employees to start up their businesses (See Table 2).

We also found that firms Equally owned by Latinos and non-Latinos had a higher dependence on trade credit $(85.0 \%)$ and credit cards $(80.5 \%)$, with rates 5 to 8 percentage points higher than those for Latinoowned firms. It is also important to note that financial institutions funded White-owned firms through loans at a higher rate $(76.4 \%)$ than Latino-owned firms (62.5\%), reflecting a 13 percentage point difference.

White-owned firms had greater access to all forms of credit offered by formal financial markets than those owned by other groups. These firms were able to obtain credit at higher rates than Latino-owned and Equally Latino and non-Latino-owned firms. White-owned firms obtained credit from suppliers (87\%), credit cards (84\%), and family and friends (74.5\%). Only in two sources of credit, Angel Investors (47.2\%) and Other Investors (53.7\%), was there a tendency for Latino-owned firms to have higher rates than Equally Latino and non-Latino-owned firms. 
Table 2 provides figures for firms with less than 2 years in business, including start-up firms or businesses with only a few months of operation. The top funding sources (trade credit, credit cards, and family, friends, and employees) for the three types of firms included in this study rank similarly for all firms, but at different percentages. Lack of strong business relationships with suppliers, short credit history, and lower credit scores likely explain the lower rates among Latino and Equally Latino and non-Latinoowned firms. White-owned firms have higher access to credit from all the funding sources than do Latinoowned firms, except from Other Investors. White-owned firms also have higher access to most funding sources than Equally Latino and non-Latino-owned firms. White businesspersons are more likely to be native-born, which makes their family and friendships networks extensive and diverse; this may help explain the $12.3 \%$ gap in funding from these sources with Latino-owned firms. Differences in wealth among family and friends of these two groups could provide another explanation for the differential access to external funding.

TABLE 2

\section{FUNDING SOURCES FPR START-UP BUSINESSES BY RACE/ETHNICITY OF OWNERS - 3 YEAR AVERAGE (PERCENTAGES; 2014, 2015, 2016)}

\begin{tabular}{|c|c|c|c|c|c|c|}
\hline \multirow[b]{2}{*}{ Funding Source } & \multicolumn{3}{|c|}{ All Firms } & \multicolumn{3}{|c|}{$\begin{array}{c}\text { Firms with less than } \\
2 \text { years in Business }\end{array}$} \\
\hline & Latino & $\begin{array}{c}\text { Eq. } \\
\text { Latino \& } \\
\text { Non- } \\
\text { Latino }\end{array}$ & White & Latino & $\begin{array}{c}\text { Eq. } \\
\text { Latino \& } \\
\text { Non- } \\
\text { Latino }\end{array}$ & White \\
\hline Owner & 58.2 & 58.2 & 67.2 & 55.3 & 56.3 & 66.1 \\
\hline Family, Friends, \& Employees & 67.4 & 69.8 & 74.5 & 60.8 & 60.9 & 73.1 \\
\hline $\begin{array}{l}\text { Banks, Credit Unions \& Other } \\
\text { Financial Institutions }\end{array}$ & 62.5 & 70.0 & 76.4 & 53.9 & 48.2 & 65.9 \\
\hline Home Equity Loans & 59.1 & 60.9 & 71.7 & 49.7 & 54.5 & 67.4 \\
\hline Credit Cards & 75.9 & 80.5 & 84.0 & 70.5 & 76.3 & 79.0 \\
\hline Trade Credit (buy now, pay later) & 76.9 & 85.0 & 87.1 & 75.3 & 79.4 & 80.6 \\
\hline Angel Investors & 47.2 & 27.2 & 47.3 & 45.1 & 43.6 & 53.1 \\
\hline Venture Capitalists & 34.9 & 50.8 & 44.1 & 35.1 & 39.2 & 46.1 \\
\hline Other Investor & 53.7 & 41.6 & 52.5 & 52.7 & 56.8 & 49.2 \\
\hline Crowd Funding & 43.6 & 62.1 & 52.2 & 26.4 & 65.2 & 50.1 \\
\hline Grants & 45.8 & 47.2 & 51.8 & 42.1 & 56.9 & 47.8 \\
\hline
\end{tabular}

Source: U.S. Bureau of the Census, Survey of Entrepreneurs - 2014, 2015, 2016.

https://www.census.gov/library/publications/2012/econ/2012-sbo.html

The range and quality of the social and business relationships White businesspeople have in comparison to Latino business owners may also explain the gap in access to external funding sources listed in Table 2. Whites tend to rely more on their "weak" relationships, while Latinos focus on their "strong" relationships (Granovetter, 1973). Whites are more transactional while Latinos are more personal in their orientations. Differences in the type of relationships or ties have an impact at the time of seeking financial funds to start up a business.

\section{Funding Amounts by Sources}

We also estimated the funding amounts the three types of firms were able to obtain from different sources to conduct their operations between 2014 and 2016. Table 3 shows LOBs obtained financial resources mainly from the owners' savings $(62.8 \%)$, from banks and other financial institutions (34.1\%), and from family, friends, and employees (16.2\%). White business owners also obtained credit from the 
same sources, but at lower rates than LOBs. They obtained funds from owner's savings (50.7\%), from banks and other financial institutions (33.8\%), and from family, friends, and employees (10.1\%). Both White- and Latino-owned businesses obtained credit funds from these three funding sources mainly in the ranges of $\$ 10,000$ to $\$ 24,999$ and $\$ 250,000$ and more, which shows that LOBs with large operations were able to access credits for large sum of monies.

TABLE 3

FUNDING SOURCES AMONG RACIAL/ETHNIC BUSINESS OWNERS BY AMOUNTS 3 YEAR AVERAGE (PERCENTAGES; 2014, 2015, 2016)

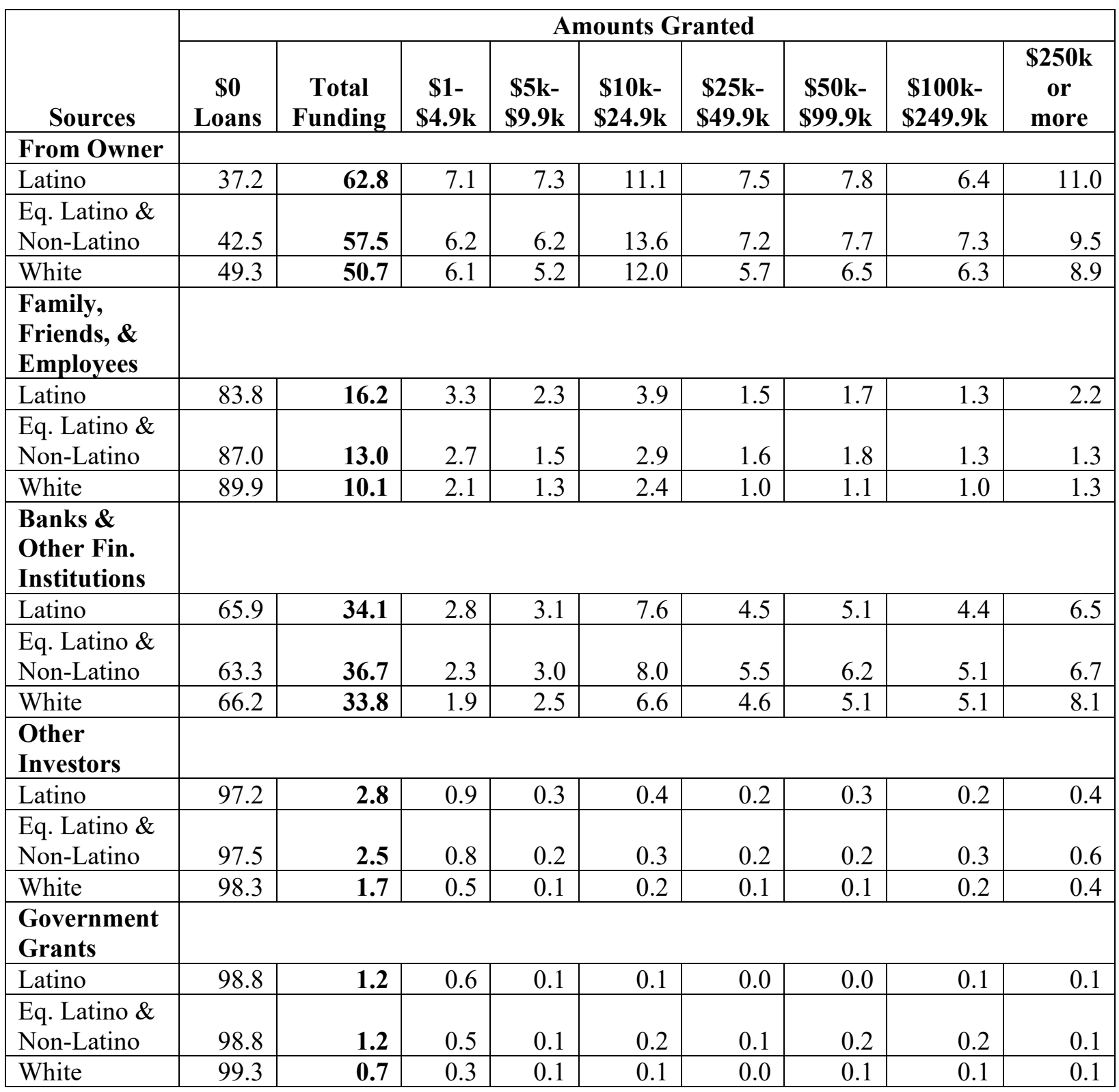

Source: U.S. Bureau of the Census, Survey of Entrepreneurs, 2014, 2015, 2016.

https://www.census.gov/library/publications/2012/econ/2012-sbo.html

In addition, the groups had access to funds from two other funding sources: 1) other investors such as Angel investors and Venture capitalists; and 2) government grants, although at lower rates than for the three 
main sources of funding described above. The funding amounts obtained from these sources were low and mainly within the range of $\$ 1$ to $\$ 4,999$. The low percentage of firms with access to these two funding sources could be explained by either difficulty in obtaining these funds or the lack of knowledge that most of these firms have about external investors. On the other hand, government grants require a detailed proposal from business owners and Latinos, in most cases, do not have the knowledge and experience on how to submit a carefully crafted proposal to the government agency.

\section{TABLE 4 \\ FUNDING SOURCES AMONG RACIAL/ETHNIC BUSINESS OWNERS WITH FIRMS WITH LESS THAN 2 YEARS IN BUSINESS BY AMOUNTS - 3 YEAR AVERAGES (PERCENTAGES; 2014, 2015, 2016)}

\begin{tabular}{|c|c|c|c|c|c|c|c|c|c|}
\hline \multirow[b]{2}{*}{ Sources } & \multicolumn{9}{|c|}{ Amounts Received } \\
\hline & $\$ 0$ & $\begin{array}{c}\text { Total } \\
\text { Funding }\end{array}$ & $\begin{array}{c}\$ 1- \\
\$ 4.9 \mathrm{k} \\
\end{array}$ & $\begin{array}{l}\$ 5 \mathrm{k}- \\
\$ 9.9 \mathrm{k}\end{array}$ & $\begin{array}{l}\$ 10 \mathrm{k}- \\
\$ 24.9 \mathrm{k}\end{array}$ & $\begin{array}{l}\$ 25 \mathrm{k}- \\
\$ 49.9 \mathrm{k}\end{array}$ & $\begin{array}{l}\$ 50 \mathrm{k}- \\
\$ 99.9 \mathrm{k}\end{array}$ & $\begin{array}{l}\$ 100 k- \\
\$ 249.9 k\end{array}$ & $\begin{array}{c}\$ 250 k \\
\text { or } \\
\text { more }\end{array}$ \\
\hline \multicolumn{10}{|l|}{ From Owner } \\
\hline Latino & 21.9 & 78.1 & 8.3 & 9.9 & 19.5 & 10.1 & 9.2 & 7.6 & 13.4 \\
\hline $\begin{array}{l}\text { Eq. Latino \& } \\
\text { Non-Latino }\end{array}$ & 27.8 & 72.2 & 9.5 & 6.1 & 14.6 & 9.8 & 11.9 & 10.4 & 9.8 \\
\hline White & 31.4 & 68.6 & 8.3 & 7.1 & 16.0 & 8.1 & 8.9 & 8.2 & 12.0 \\
\hline \multicolumn{10}{|c|}{$\begin{array}{l}\text { Family, Friends, } \\
\text { \& Employees }\end{array}$} \\
\hline Latino & 75.9 & 24.1 & 4.4 & 3.7 & 5.9 & 2.4 & 2.4 & 2.2 & 3.3 \\
\hline $\begin{array}{l}\text { Eq. Latino \& } \\
\text { Non-Latino }\end{array}$ & 83.5 & 16.5 & 3.5 & 2.4 & 1.8 & 1.5 & 1.8 & 2.5 & 2.0 \\
\hline White & 83.9 & 16.1 & 3.0 & 2.1 & 3.7 & 1.7 & 1.8 & 1.6 & 2.2 \\
\hline \multicolumn{10}{|c|}{$\begin{array}{l}\text { Banks \& Other } \\
\text { Fin. } \\
\text { Institutions*** }\end{array}$} \\
\hline Latino & 67.6 & 32.4 & 3.5 & 3.5 & 8.4 & 4.3 & 3.5 & 3.3 & 5.8 \\
\hline $\begin{array}{l}\text { Eq. Latino \& } \\
\text { Non-Latino }\end{array}$ & 66.4 & 33.6 & 2.0 & 4.3 & 7.9 & 3.1 & 4.4 & 4.7 & 7.2 \\
\hline White & 67.6 & 32.4 & 2.6 & 3.0 & 7.2 & 4.6 & 4.5 & 4.1 & 6.5 \\
\hline \multicolumn{10}{|c|}{ Other Investors } \\
\hline Latino & 95.8 & 4.2 & 1.0 & 0.5 & 0.7 & 0.5 & 0.3 & 0.2 & 1.0 \\
\hline $\begin{array}{l}\text { Eq. Latino \& } \\
\text { Non-Latino }\end{array}$ & 96.2 & 3.8 & 0.6 & 0.7 & 0.2 & 0.0 & 0.0 & 0.5 & 1.5 \\
\hline White & 96.7 & 3.3 & 0.7 & 0.2 & 0.4 & 0.2 & 0.3 & 0.5 & 1.1 \\
\hline \multicolumn{10}{|l|}{ Gov. Grants } \\
\hline Latino & 98.4 & 1.6 & 0.8 & 0.2 & 0.2 & 0.2 & 0.0 & 0.1 & 0.1 \\
\hline $\begin{array}{l}\text { Eq. Latino \& } \\
\text { Non-Latino }\end{array}$ & 98.1 & 1.9 & 0.7 & 0.0 & 0.3 & 0.3 & 0.0 & 0.6 & 0.0 \\
\hline White & 99.1 & 0.9 & 0.4 & 0.1 & 0.1 & 0.0 & 0.1 & 0.1 & 0.1 \\
\hline
\end{tabular}

Source: U.S. Bureau of the Census, Survey of Entrepreneurs, 2014, 2015, 2016. https://www.census.gov/library/publications/2012/econ/2012-sbo.html

Table 4 shows the 3-year average percentage of funding from different funding sources for firms with less than 2 years in business. We observe similar patterns across all firms, but at different rates in most of the funding sources except for loans obtained from banks and other financial institutions. Still in the launch phase, their lack of business experience may explain in part the slightly lower amounts of funds obtained from financial institutions. On the other hand, mature firms have easier access to credits from financial 
institutions due to their credit history, well-developed business plans, high business credit scores, and physical guarantees that back-up the loans as collateral.

The percentages of credit that start-up firms were able to obtain from the different funding brackets were like the ones obtained by all firms. As was the case for all firms, the funding bracket from $\$ 10,000$ to $\$ 24,999$ shows the highest percentages of all funding sources among the three business ownership groups included in the study. Table 4 also shows the three groups obtained loans for more than $\$ 250,000$ in relatively higher percentages.

\section{REASONS WHY LATINO BUSINESSES AVOID EXTERNAL FUNDING}

Table 5 provides figures on the reasons provided by business owners for avoiding external funding. The first part of Table 5 provides figures on whether businesses need or do not need additional funds for their operations. The first row shows the percentages of business owners from the three groups reporting the need for additional funding. Among All Firms, higher percentages of those Equally owned by Latinos and non-Latinos (13.0\%) and Latinos (12.2\%) indicated needing additional funding than White firms $(8.3 \%)$. The same pattern is evident among Firms with less than 2 years in Business. On the second row are percentage figures for those firms that did not indicate a need for additional funding. In both All Firms and those with Less than 2 Years in Business, more White-owned firms indicated they did not need additional funds, 91.7\% for All Firms and 89.2\% for start-ups.

In both major firm categories, there is close to a $4.0 \%$ gap in the need for additional funding between LOBs and White-owned businesses. Since LOBs reported having to rely mainly on their own savings and loans from their family and friends as funding sources, this likely induces them to search for additional funds at slightly higher rates than their White counterparts.

The second part of the table provides percentage figures on the reasons that firms avoid applying for credit from banks and other financial institutions. In both categories of firms, Equally Latino and nonLatino-owned firms had the highest percentages not wanting to accrue debt, followed by Latino-owned firms. It is interesting to note that Latino-owned and Equally Latino and non-Latino-owned firms decided the finance costs would be too high as a reason for not applying for a loan. We suggest that these higher percentages are due to lack of trust on the part of business owners, well-established social capital among the two groups of investors, and the lack of previous business experience and the necessary guarantees to support new loans as collateral.

Start-up firms were more likely to avoid debt and to believe that a loan would not be approved. This may be due to lack of business experience or perceived discrimination. Their lack of or limited business experience is indicated by the fact they that many do not have a well-developed business plan including the necessary financial statements, have low personal/business credit scores, and lack assets to back up the loan.

Firms with less than 2 years in business reported higher percentages across all the reasons for not applying for loans, compared with the figures for All Firms (see Table 5). Possible explanations for the higher percentages include a high number of newcomers in these firms who did not have business experience to back up their operations. They did not have well established long-term relationships with financial institutions, have an aversion to debt, and avoided risk. Finally, these firms did not have the required guarantees to support new loans as collateral.

White-owned firms reported lower rates for all the reasons for not applying for additional funds presented on Table 5. Only $4.7 \%$ of these firms reported they did not want to accrue debt as their main reason for not applying for new loans, reflecting a 2.7\% gap with Latino-owned firms. A possible explanation is that these firms have been operating for a long time, have more business experience, and are able to reinvest their profits, which allows them to not have to rely on additional external funding for their operations. These businesspersons are somewhat less concerned about accruing debt and its cost. They also expect financial institutions will approve additional funding for them because they can fulfill all or most of the requirements from banks and other financial institutions for granting loans. 
TABLE 5

REASONS FOR AVOIDING EXTERNAL FUNDING BY FIRMS AND RACE/ETHNICITY 3 YEAR AVERAGE (PERCENTAGES; 2014, 2015, 2016)

\begin{tabular}{|c|c|c|c|c|c|c|}
\hline \multirow[b]{2}{*}{ Reasons } & \multicolumn{3}{|c|}{ All Firms } & \multicolumn{3}{|c|}{$\begin{array}{l}\text { Firms with less than } \\
2 \text { years in Business }\end{array}$} \\
\hline & Latino & $\begin{array}{c}\text { Eq. } \\
\text { Latino \& } \\
\text { Non- } \\
\text { Latino }\end{array}$ & White & Hispanic & $\begin{array}{c}\text { Eq. } \\
\text { Latino \& } \\
\text { Non- } \\
\text { Latino }\end{array}$ & White \\
\hline $\begin{array}{l}\text { Business needs Additional Funding } \\
\text { and Apply }\end{array}$ & 12.2 & 13.0 & 8.3 & 14.2 & 14.7 & 10.8 \\
\hline $\begin{array}{l}\text { Business did not need Additional } \\
\text { Funding }\end{array}$ & 87.8 & 87.0 & 91.7 & 85.8 & 85.3 & 89.2 \\
\hline $\begin{array}{l}\text { Reasons for not seeking additional } \\
\text { funds }\end{array}$ & & & & & & \\
\hline $\begin{array}{l}\text { Did not think additional funding } \\
\text { would be approved by lender }\end{array}$ & 6.1 & 6.0 & 3.4 & 7.4 & 8.5 & 5.1 \\
\hline Did not want to accrue debt & 6.7 & 7.4 & 4.7 & 7.9 & 8.4 & 6.2 \\
\hline $\begin{array}{l}\text { Decided finance cost would be too } \\
\text { high }\end{array}$ & 3.6 & 3.8 & 2.2 & 4.4 & 5.7 & 2.9 \\
\hline Preferred to reinvest business profits & 1.9 & 1.9 & 1.1 & 2.7 & 3.0 & 1.6 \\
\hline $\begin{array}{l}\text { Felt loan application process would } \\
\text { be too time consuming }\end{array}$ & 1.7 & 2.1 & 1.2 & 1.8 & 1.6 & 1.6 \\
\hline $\begin{array}{l}\text { Decided the additional funding was } \\
\text { no longer needed }\end{array}$ & 0.6 & 0.7 & 0.4 & 0.8 & 0.9 & 0.4 \\
\hline $\begin{array}{l}\text { Decided to wait until funding could } \\
\text { improve }\end{array}$ & 1.9 & 1.7 & 1.0 & 2.3 & 2.7 & 1.3 \\
\hline $\begin{array}{l}\text { Decided to wait until company hit } \\
\text { milestone to be in a stronger position } \\
\text { to raise funds }\end{array}$ & 1.5 & 1.5 & 1.0 & 2.4 & 2.8 & 1.7 \\
\hline Other reasons for not applying & 0.6 & 0.8 & 0.5 & 0.6 & 1.3 & 0.8 \\
\hline
\end{tabular}

Source: U.S. Bureau of the Census, Survey of Entrepreneurs - 2014, 2015, 2016

https://www.census.gov/library/publications/2012/econ/2012-sbo.html

\section{THE SUPPLY SIDE OF FINANCIAL MARKETS}

Several studies show the important role Latino-owned businesses play within the U.S. economy due to their steady growth both in numbers and market share. Banks have noticed the huge business opportunities LOBs offer and are taking steps and making internal adjustments to attract them and facilitate their participation in the formal financial markets by offering products especially tailored for the Latino community and establishing long-term relationships based on mutual trust.

The Federal Deposit Insurance Corporation (FDIC) reports substantial percentages of unbanked Latino households, $17.9 \%$ in 2013 and $14.0 \%$ in 2017. Even though there was a decline of $3.9 \%$ between 2013 and 2017, the percentage of unbanked Latino households is still very high. In a similar way, the percentage of underbanked Latino households also show a decline of $0.4 \%$ between 2015 to 2017 from $29.3 \%$ in 2015 to $28.9 \%$ in 2017. The total percentage of unbanked and underbanked Latino households in 2017 was equal to $42.9 \%$. These figures show the potential opportunities that exist for banks and other financial institutions to attract new Latino customers.

A report from the Latino Entrepreneurship Initiative (LEI) by Orozco, Oyer, and Porras (2017) states that Latinos have the highest rate of new entrepreneurs ... Latino firms have continued to rise since 2012, 
which indicates that the opportunity gap has also grown. In today's dollars, that is about $\$ 70$ billion more, or $\$ 1.47$ trillion" (LEI, 2017, p. 4). The authors define the opportunity gap as "the difference between the average annual revenues of Latino vs. non-Latino owned firms (p. 4). In addition, the authors argue that "The creation rate of U.S. Latino-owned firms continue to rise, they currently compose more than $40 \%$ of all minority-owned firms" (LEI, 2017, p. 6).

Other data related to Latino-owned businesses show that their total sales and receipts in 2012 reached $\$ 474$ billion, an increase of 35.1\% from 2007 (U.S. Bureau of the Census, Economic Census, 2012). The same dataset shows that $36 \%$ of LOBs reported an increase in the number of jobs created in the last 12 months. Latino immigrants create more businesses, and their rate of business ownership is higher than for U.S.-born Latinos and comparable to that of non-Latino owners (Fairlie, 2018). In addition, the purchasing power of Latinos has been estimated over $\$ 1.4$ billion per year, while the revenues generated by LOBs are over $\$ 700$ million per year (Geoscape, 2017). As a result of the increasing presence of LOBs in the U.S. economy lending to LOBs has become a $\$ 1.4$ billion market opportunity (Salas, 2016).

\section{How Banks Evaluate Credit Applications}

According to the FDIC, there are two approaches banks utilize to evaluate credit applications. The first is the structured approach used mainly by nationally chartered big banks and consists of well-structured procedures loan officers follow to evaluate a loan application. It includes a careful review of the applicant's business plan and financial statements, followed by an evaluation of standard financial ratios, personal and business credit scores, business experience and managerial capabilities of the operators, and the guarantees offered as collateral. After a careful review of each of these elements, loan officers assign a score to them. A final score results from the addition of all the component scores. If the resulting score is equal to or greater than the minimum score required, the bank approves the loan. Usually, these loan applications can be done electronically; the applicant only visits a bank to sign the loan contract once his/her application is approved.

Small state or local chartered banks use the relationships approach to evaluate loan applications. These banks and their local customers develop long-term social and business relationships based on mutual trust developed through the participation of bank officers in community organizations and events where they have the opportunity to interact with their customers (Siles, Robison \& Hanson, 1994b). Loan applicants who are longtime bank customers are known at the personal level because they regularly visit the bank's agency to deposit funds in their accounts or to perform other financial transactions, and to make investments in social capital with bank administrators and loan officers.

Loan officers consider their social and business relationships with the loan applicant in the loan evaluation process. Many of these customers run small businesses and do not have one or two of the following requirements: 1) a well-developed business plan, 2) up-to-date financial statements, 3) strong credit scores, and 4) a physical guarantee as collateral. In most of these applications, loan officers often are flexible in their evaluations. In some cases, however, top administrators, based on their auditors' opinions who are trying to comply with FDIC regulations, reject these approvals. Since a high percentage of LOBs are small businesses and owners prefer personal relations with bank administrators, they usually choose to work with small banks.

Regardless of their ethnicity, small business owners reported greater success at getting a loan approved or obtaining a line of credit or cash advance at small banks. LOBs report a $60 \%$ credit success at small banks, compared with $31 \%$ of applicants at large banks (Acevedo, 2018). Latinos who obtain a business loan are more likely to use personal guarantees such as cash, real estate, and other assets to secure the loan than are non-Latino White business owners.

Trust becomes a key ingredient for the development of any type of relationship. It needs to be mutual and can increase through time and continual interactions among the parties involved in the relationship. Developing trust with customers is a necessary condition for bankers and loan officers to attract new customers, especially Latinos, and to maintain the current ones. Salas argues that "Banks and non-

depository lenders must rebuild confidence among LOBs who have lost trust in them ... First generation Latino immigrants over-index relative to non-Latinos in distrust in financial institutions ... This trend must 
be reversed by building a sustainable lending model that aligns long-term economic incentives between both borrowers and lenders" (2016, p. 8).

\section{Bank Programs to Attract Latino Customers}

The following are some of the programs that banks are currently implementing to serve Latino communities and attract new Latino customers.

a) Paycheck Cashing: given the high percent of unbanked Latinos who currently cash their paychecks at local stores, banks are offering these services with lower fees or no fees at all. To reduce the risk of cash losses, banks are offering debit cards that can be used at any ATM and are reloaded with the next paycheck.

b) Savings Accounts: after a few months of cashing paychecks and starting to develop trusting relationships, banks encourage their new customers to open savings accounts with a low percentage of their income.

c) Small Loans: as a next step, banks offer small loans to help their customers start a credit history.

d) Remittances: Latin American immigrants sent an estimated $\$ 74.3$ billion to their original countries in 2016. Because these estimates do not include the transfer of other assets, such as gifts or informal monetary transfers, it is likely that the total amount is quite likely much larger than what is reported (Budiman and Connor, 2018). A high percentage of these monetary transfers are done outside the banking system. Banks want to be part of this very profitable business, and so some of them are charging lower fees and offering related services at extra hours and on weekends.

\section{Factors That Prevent Banks From Attracting More Latino Customers}

Banks are regulated and must comply with state and federal policies and regulations in carrying out their operations. At the national level is the Federal Deposit Insurance Corporation, one of two independent agencies created by the Federal Government to ensure monetary deposits in U.S. depository institutions. The other is the National Credit Union Administration, which regulates and insures credit unions. To prevent losses, these organizations prevent bank administrators from being too aggressive or flexible when recruiting new customers. They also prevent banks from offering products that could become risky for their operations.

Bank administrators and loan officers report to upper management and a bank's Board of Directors, who are interested in increasing the bank's profitability by increasing the revenue and reducing costs. At the same time, they need to comply with internal policies and regulations by upper management, which could harm or block new initiatives bank administrators are trying to implement to attract many Latino customers. Change requires support by upper management and the Board of Directors.

\section{CONCLUSION}

This study shows the important role that Latino-owned businesses currently play within the U.S. economy, although the full effects of the SARS-COV-2 pandemic are still unknown. Their numbers have increased significantly over the last 30 years through 2019, with the amount of their sales and receipts up over $\$ 400$ billion per year. Until 2020, they were also continually creating new jobs. There are many factors that help explain this pattern: The steady growth of the Latino population, the discrimination and other challenges Latinos face in the labor markets, which induce them to start a business to generate income to support their families, and the influx of Latino immigrants from Cuba, Central, and South America with high levels of education, strong business backgrounds, and extended business relationships in the U.S. and abroad.

Although these are important achievements, the Latino population and LOBs face several internal and external constraints when deciding to start a business in this country which are especially important when seeking external funding. This study shows the gaps in the sources of credit and the amounts of credit obtained between Latino- and White-owned businesses. Banks and other financial institutions have begun 
to recognize the prevalence of these gaps and the size and importance of Latino-owned businesses and households within financial markets. For this reason, in the last few years they have begun adopting new policies and practices to attract new customers and better serve this community. As in the case of the demand side, they are dealing with internal and external factors that guide them to provide better services based on new products, make cultural changes when hiring and training new staff, and comply with new policies and regulations emanated from their upper management and external regulators. These findings promote broad understanding of LOB operations, the constraints they face, and approaches for eliminating some of the constraints.

Banks have been making important changes within their procedures, personnel, products that they offer, and physical modifications at their main offices and agencies to attract more Latino households and LOBs. The following are some of the changes banks must continue to make in order to develop long-term financial relationships with Latino households and LOBs: 1) Implement programs aimed to create and develop trust with their customers. As a first step, they should offer services in Spanish and change their internal culture by hiring bilingual, bicultural friendly staff; 2) Open branches in predominantly Latino neighborhoods to facilitate access by LOBs and families to their services; 3) Design flexible, easy to understand products in Spanish suitable for Latino households and LOBs; 4) Offer financial education programs especially designed for the Latino community; and 5) Develop outreach programs to reach business owners and community members. The physical configuration of the branches ought to welcome Latino customers. Programs should provide information on how to open a checking and savings account, account management, applying for a credit card and/or a loan, managing a loan, and establishing a credit history, as well as information about credit scores and how to use mobile banking. Financial education programs for LOBs should center on how to develop and understand financial statements, balance sheets, and income statements, and to create a business plan. Finally, financial entities should actively participate in community-serving organizations and events. These services will likely be needed with greater urgency as LOBs struggle to recover from the pandemic.

\section{REFERENCES}

Acevedo, N. (2018). More Latinos own businesses but can't get capital to grow. Retrieved from https://www.nbcnews.com/news/latinos/more-latinos-own-businesses-can-t-get-capital-growreport-n93596/

Bernstein, R. (2016). Hispanic-Owned Businesses on the Upswing. U.S. Bureau of the Census, Blog. Retrieved from https://www.census.gov/newsroom/blogs/random-samplings/2016/12/hispanicowned busin.html

Budiman, A., \& Connor, P. (2018). Migrants from Latin America and the Caribbean sent a record amount of money to their home countries in 2016. FactTank - News in the Numbers. Retrieved from https://www.pewresearch.org/fact-tank/2018/01/23/migrants-from-latin-america-and-thecaribbean-sent-a-record-amount-of-money-to-their-home-countries-in-2016/

BusinessWire. (2017). Study: U.S. Hispanic Businesses Continue Steady Growth, 4.4 million Firms will contribute $\$ 709$ Billion to the U.S. Economy in 2017. Retrieved from https://www.businesswire.com/news/home/20171002005951/en/Study-U.S.-HispanicBusinesses-Continue-Steady-Growth

Carpenter, C.W., \& Loveridge, S. (2018). Differences Between Latino-Owned Businesses and White-, Black-, or Asian-Owned Businesses: Evidence from Census Microdata. Economic Development Quarterly, 32(3), 225-241.

Coronado, J., \& Martinez, R. (2018). Hicimos el Camino en Michigan: Latino Business Pioneers. Dialogo: An Interdisciplinary Studies Journal, 21(1), 51-65.

Dávila, A., \& Mora, M.T. (2013). Hispanic Entrepreneurs in the 2000s, An Economic Profile and Policy Implications. Stanford University Press, Stanford, California.

Fairlie, R. (2018). Latino Business Ownership: Contributions and Barriers for U.S.-born and Immigrant Latino Entrepreneurs. Economic Consulting for U.S. Small Business Administration Office of 
Advocacy. Retrieved from https://www.sba.gov/sites/default/files/Latino-Business-OwnershipResearch-Paper_.pdf

Federal Deposit Insurance Corporation. (2017). FDIC National Survey of Unbanked and Underbanked Households. Federal Deposit Insurance Corporation, Division of Depositor and Consumer Protection. Retrieved from https://www.fdic.gov/householdsurvey/2017/2017report.pdf

Flores, A. (2017). 2015, Hispanic Population in the United States Statistical Portrait. Pew Research Center. Retrieved from https://www.pewresearch.org/Hispanic/2017/09/18/2015-statisticalinformation-on-hispanics-in-united-states/

Geoscape. (2017). Hispanic Businesses \& Entrepreneurs Drive Growth in the New Economy. $5^{\text {th }}$ Annual Report, 2017. Retrieved from https://ushcc.com/2017-geoscape-report/

Granovetter, M.S. (1873). The Strength of Weak Ties. AJS, 78(6), 1360-1381.

Hamilton, D., Fienup, M., Hayes-Bautista, D., \& Hsu, P. (2019). LDC U.S. Latino GDP Report: Quantifying the New American Economy. Thousand Oaks, CA: Center for Economic Research and Forecasting, California Lutheran University. Retrieved from https:/hispanicexecutive.com/wp-content/uploads/2019/12/LDC_US_LatinoGDP_2019-final.pdf

Hipple, S. (2010, September). Self-employment in the United States. Monthly Labor Review, pp. 17-32. Retrieved from https://www.bls.gov/opub/mlr/2010/09/art2full.pdf

Kauffman Foundation. (2016). Kauffman Index of Entrepreneurial Activity. Retrieved from www.kauffman.org

Kelderehouse, E.R. (2002, Fall). Banking Latino Immigrants: A Lucrative New Market for Progressive Financial Institutions. Federal Reserve Bank of St. Louis. Retrieved from https://www.stlouisfed.org/publications/bridges/fall-2002/banking-latino-immigrants-a-lucrativenew-market-for-progressive-financial-institutions?print=true

Light, I., \& Bonacich, E. (1988). Immigrant Entrepreneurs, Koreans in Los Angeles 1965-1982. University of California Press, Berkley and Los Angeles, California.

Martinez, R., \& Avila, B. (2019). Motivations for Entrepreneurship among Mexican Americans and White Americans. International Journal of Social Science and Business, 4(1), 1-12.

Martinez, R.O., Avila, B., Santiago, O., \& Tello Buntin, J. (2011). Latino-Owned Businesses: Startup Fund Sources and Implications in Comparison to Other Racial/Ethnic Groups. Research Report 48. East Lansing, MI: Julian Samora Research Institute, Michigan State University.

New American Economy. (2017, December). How Hispanics Contribute to the U.S. Economy. Unidos US. Retrieved from http://research.newamericaneconomy.org/wpcontent/uploads/sites/2/2017/12/Hispanic_V5.pdf

Olivas, D., \& Frankwick, G.L. (2016). Understanding Hispanic Entrepreneurial Success: An Exploratory Study. Journal of Business Diversity, 16(1). Retrieved from https://articlegateway.com/index.php/JBD/article/view/1893

Orozco, M., Oyer, P., \& Porras, J.I. (2018). State of Latino Entrepreneurship. 2017 Research Report. Stanford Graduate School of Business. Retrieved from https://www.gsb.stanford.edu/sites/default/files/publication-pdf/report-slei-state-latinoentrepreneurship-2017.pdf?pid=

Orozco, M., Tareque, I.S., Oyer, P., \& Porras, J.I. (2020). State of Latino Entrepreneurship. 2019 Research Report. Stanford Graduate School of Business. Retrieved from https://www.gsb.stanford.edu/sites/default/files/publication-pdf/report-slei-state-latinoentrepreneurship-2019.pdf?pid=Stanford_ExecEd-1284684363.1602349452

Prudential Research. (2014). The Hispanic American Financial Experience. Prudential. Retrieved from https://docplayer.net/8074983-The-hispanic-american-financial-experience-2014-prudentialresearch.html

Quezada, D. (2018). The State of Latino Entrepreneurship in 2017: What you need to know? Retrieved from https://prosperitynow.org/blog/state-latino-entrepreneurship-2017-what-you-need-know/

Rengert, K., \& Rhine, S. (2016). Bank Efforts to Serve Unbanked and Underbanked Consumers: Qualitative Research. Federal Deposit Insurance Corporation, Division of Depositor and 
Consumer Protection, pp. 1-37. Retrieved from https://www.fdic.gov/consumers/community/research/qualitativeresearch_may2016.pdf

Salas, S. (2016). Lending to Latino-Owned Businesses: A \$1.4 Billion Market Opportunity. Forbes, pp. 1-9. Retrieved from https://www.forbes.com/sites/groupthink/2016/11/01/lost-americanopportunity-lending-to-latino-businesses/\#3e409f24a1 da

Siles, M.E., Hanson, S.D., \& Robison, L.J. (1994a). Socio-Economics and the Probability of Loan Approval. Applied Economic Perspectives and Policy, 16, 366-372.

Siles, M.E., Robison, L.J., \& Hanson, S.D. (1994b). Does Friendly Service Retain Customers. Bank Marketing, 26, 47-47.

Starr, A. (2012, July). Latino Immigrant Entrepreneurs: How to Capitalize on Their Economic Potential. Working paper, Council on Foreign Relations, New York.

U.S. Bureau of the Census. (n.d.). Economic Census 2012. Retrieved from https://www.census.gov/data/developers/data-sets/economic-census.2012.html

U.S. Bureau of the Census. (n.d.). Survey of Business Owners, 1992-2012. Retrieved from https://www.census.gov/library/publications/2012/econ/2012-sbo.html

United States Hispanic Chamber of Commerce (USHCC). (2017). Study: U.S. Hispanic Businesses Continue Steady Growth. Retrieved from https://cstoredecisions.com/2017/10/03/sudy-u-shispanic-businesses-continue-steady-growth/

Williams, D.E., Gavino, M.C., \& Jacobson, D.W. (2017). Latino Entrepreneurs and Technology Usage: Ethnic Identity, Resistance, Self-Efficacy. Journal of Business Diversity, 17(1). Retrieved from https://articlegateway.com/index.php/JBD/article/view/1214 